\title{
Ekonomia komunii w relacji do ekonomii społecznej - analogie, różnice, szansa na współdziałanie
}

\section{Stanisław Grochmal*}

Streszczenie: Dwie idee działań ekonomicznych: ekonomia komunii i ekonomia społeczna, starające się wypełnić lukę pomiędzy biznesem (ekonomia rynku) a państwem (dystrybucja dóbr), dążące do ograniczenia ubóstwa i wykluczenia społecznego, mają wiele cech wspólnych, a w niektórych aspektach istotnie się różnią. Artykuł umożliwia zrozumienie idei ekonomii komunii w odniesieniu do ekonomii społecznej i jej realizacji oraz wobec zadań biznesowych i społecznych, jakich podejmują się przedsiębiorcy ekonomii komunii. W artykule wykazano dużą zbieżność obydwu idei ekonomicznych oraz szanse na wzajemne uzupełnianie się i współdziałanie dla konkretnych celów społecznych.

Słowa kluczowe: ekonomia społeczna, ekonomia komunii, ubóstwo, wykluczenie społeczne, Ruch Focolari.

\section{Wprowadzenie}

Klasyczna ekonomia rynku nie jest w stanie rozwiązać licznych i ważnych kwestii współczesnych społeczeństw: ogromnych nierówności społecznych, poczucia zagrożenia (także wśród bogatych), utraty sensu relacji międzyosobowych oraz kryzysu ekonomicznego, a de facto etycznego. Wyłączne kryterium efektywności i zysku oraz działania rynku pozbawionego często zasad moralnych nie pozwalają na rozwiązanie poważnych problemów społecznych, bezrobocia, coraz powszechniejszej biedy, wykluczenia społecznego czy degradacji środowiska.

Współczesna ekonomia, aby powrócić do swojej zasadniczej roli, jaką jest uszczęśliwienie człowieka, winna odwołać się do swoich korzeni aksjologiczno-antropologicznych oraz etycznych, nie rezygnując jednak z wartości, jakie rynek wnosił i wnosi w zakresie indywidualnej wolności i równości. Niezbędne jest jednak uwzględnianie w procesach ekonomicznych tego, co do niedawna było całkowicie pomijane - relacji braterstwa, solidarności i wzajemności.
Dychotomiczny podział działalności ekonomicznych na for profit i non profit, przy dominującym nadal modelu homo oeconomicus, sprzyja ignorowaniu tego, co jest pośrodku:

W narzuconym opinii publicznej dyskursie, opartym na fałszywej opozycji wolności i sprawiedliwości, brakuje (...) opcji bardziej wspólnotowej. Mało jest w tym dyskursie miejsca dla tych, którzy wierza, że poza wolnością i równościa powinno być miejsce dla solidarności i braterstwa wich właściwej postaci - tej, która bierze się z wolnego wyboru. (...) Jakkolwiek pompatycznie to zabrzmi, wolność, równość i braterstwo maja swoje instytucjonalne oparcie w postaci rynku, państwa oraz swobodnie stowarzyszajacego się społeczeństwa. Pomimo istniejących pomiędzy nimi napięć, kluczowe jest utrzymywanie

\footnotetext{
* Stanisław Grochmal

Państwowa Wyższa Szkoła Zawodowa im. Stanisława Pigonia w Krośnie Rynek 1, 38-400 Krosno e-mail: grochmal@rubikon.pl
} 
w równowadze wszystkich trzech elemen-

tów." [Wygnański, 2008, s. 16].

Warunkiem równowagi wspomnianych elementów jest przede wszystkim chęć dostrzeżenia pośredniego obszaru pomiędzy tymi dwoma wizjami ekonomii. Papież Benedykt XVI nazywa ten obszar „wielobarwnym światem podmiotów tak zwanej ekonomii obywatelskiej i wspólnotowej". Nie chodzi tylko o "trzeci sektor», ale o nową, obszerną i złożoną rzeczywistość, obejmującą własność prywatną i publiczną, która nie wyklucza zysku, ale uważa go za narzędzie do realizacji celów humanistycznych i społecznych [Benedykt XVI, 2009, n. 46].

Taki wspólnotowy charakter oraz humanistyczny i społeczny wymiar ma ekonomia komunii, będąca konkretnym sposobem na realizację w działalności ekonomicznej idei wzajemności i braterstwa. Jej celem nie jest transformacja przedsiębiorstw w firmy bardziej etyczne czy bardziej odpowiedzialne społecznie, ale wniesienie konkretnego wkładu w bardziej sprawiedliwy świat i zmniejszenie liczby osób zmuszonych do życia w nędzy lub wykluczonych społecznie. Ekonomia komunii patrzy na przedsiębiorstwa jak na przestrzeń generowania bogactwa oraz tworzenia miejsc pracy, bowiem te dwa procesy odgrywają szczególną rolę $w$ walce $z$ nędzą i wykluczeniem. Przedsiębiorstwa, a nie polityka publiczna czy organizacje pozarządowe, realizując projekt ekonomii komunii, mają szansę wypełnić obszar pomiędzy ekonomią for profit i non profit oraz znacznie przyczynić się do lepszego, godnego życia wielu ludzi.

Celem niniejszego artykułu jest zaprezentowanie ekonomii komunii w relacji do ekonomii społecznej, pokazanie istotnych podobieństw i różnic tych idei ekonomicznych, a przede wszystkim możliwości wzajemnego wspierania się i współdziałania. Problematyka ekonomii społecznej dla czytelników czasopisma "Ekonomia Społeczna" jest dobrze znana [Defourny, Develtere, 2008; Filek, 2009 i 2012;
Peredo, McLean, 2014; Pokora, 2014; Szopa, 2007; Wygnański, 2008], zatem w artykule ograniczono się tylko do przedstawienia tych jej aspektów, które są istotne dla analizy porównawczej z ekonomią komunii oraz ukazują wspólne źródła i cele.

\section{Ekonomia społeczna - geneza i cechy charakterystyczne}

Pojęcie ekonomia społeczna może być niekiedy uważane za przykład oksymoronu, bowiem działanie ekonomiczne jest zwykle rozumiane jako racjonalne działanie nastawione na zysk, natomiast przymiotnik „społeczny" oznacza działanie zaspakajające społeczne potrzeby ludzi, niekoniecznie tożsame z zasadą maksymalnej efektywności ekonomicznej. Jednak rozumienie ekonomii na przestrzeni lat znacznie się poszerzyło i pojęcie ekonomii społecznej posiada konkretny sens. Trudno jednak podać jedną i jedyną zarazem definicję ekonomii społecznej".

Wielu naukowców uważa ekonomię społeczną za nową dyscyplinę naukową, dla której określa się nowy paradygmat, znacznie różniący się od dotychczas obowiązującego w ekonomii klasycznej homo oeconomicus. Mając na uwadze nową wizję działalności ekonomicznej człowieka i jej wpływ na zmianę mentalności i nową kulturę cywilizacyjną wydaje się słusznym stwierdzenie, że został przekroczony pewien poziom "masy krytycznej" pozwalający na zmianę paradygmatu,

\footnotetext{
Ekonomia społeczna jest niekiedy utożsamiana z ekonomia solidarną lub alternatywną, nie są to jednak pojęcia całkowicie tożsame. Ekonomia solidarna opiera się na wymianie darów, zakładając spodziewane w przyszłości odwzajemnienie się strony obdarowanej (dar nie jest jednak uwarunkowany odwzajemnieniem). Samo pojęcie ekonomii społecznej jest przedmiotem licznych dyskusji. Niektórzy badacze uważają, że bardziej adekwatnymi byłyby pojęcia: społeczna gospodarka rynkowa, przedsiębiorczość społeczna lub ekonomia socjalna. Na przełomie XIX i XX wieku pojęcie ekonomii społecznej wiązało się z ekonomią polityczną, jednak upaństwowienie gospodarki miało niewiele wspólnego z jej uspołecznieniem, podobnie jak prywatyzacja daleka jest od spełnienia oczekiwań społecznych.
} 
a przedsiębiorstwa społeczne, stanowiące konkretny wyraz ekonomii społecznej, stały się „konstruktem społecznym" w rozumieniu Kuhna [1968].

Istotną cechą ekonomii społecznej jest jej odwoływanie się do wartości takich jak sprawiedliwość, solidarność, wolność czy odpowiedzialność społeczna. Ekonomia społeczna charakteryzuje się pod względem ekonomicznym działaniem w warunkach normalnej gospodarki rynkowej, ponoszeniem ryzyka ekonomicznego i wykorzystywaniem mechanizmów rynkowych do realizacji celów o charakterze społecznym w pełnej niezależności od instytucji publicznych.

Ze względu na kryteria społeczne należy w ekonomii społecznej wyróżnić użyteczny społecznie cel działalności (świadczenie usług dla członków i wspólnoty zamiast pełnienia instrumentalnej roli w interesie zewnętrznego kapitału), obywatelski charakter podejmowanych inicjatyw (kształtowanie postaw obywatelskich przez działanie na rzecz ludzi i aktywizację społeczności lokalnych), demokratyczny system zarządzania przez uczestnictwo (autonomiczne podejmowanie decyzji niezależnie od posiadanego kapitału przez akcjonariusza lub właściciela), wspólnotowy charakter przedsięwzięć oraz podział zysków na cele społecznie pożyteczne.

Obszerną analizę źródeł ekonomii społecznej w aspekcie ontologicznym, etycznym i antropologicznym przedstawia J. Filek [2012, s. 35-54]. W niniejszym artykule zostaną przedstawione niektóre elementy genezy ekonomii społecznej ze względu na późniejsze odniesienia do ekonomii komunii.

Nie będzie nadużyciem stwierdzenie, że źródeł ekonomii społecznej należy szukać w czasach starożytnych (Egipt, Grecja, Rzym), kiedy to człowiek przekonał się o roli społecznych relacji międzyosobowych oraz znaczeniu stowarzyszania się i życia we wspólnocie. Już wówczas istniały korporacje zawodowe, bractwa religijne i świeckie zapewniające so- lidarną i rozmaitą pomoc potrzebującym². Szczególnie zauważalny jest rozwój stowarzyszeń, cechów rzemieślniczych, a także instytucji dobroczynnych i opiekuńczych w średniowieczu. Typowymi przykładami ówczesnych instytucji społecznych były szpitale i przytułki prowadzone przez zgromadzenia zakonne. Istotne znaczenie przypisywano wówczas tworzeniu wspólnot, takich jak np. cechy rzemieślnicze, konfraternie, banki lokalne czy kasy wiejskie, rozwijające idee wzajemności, braterstwa, solidarności międzypokoleniowej, czy też troski o dobro wspólne.

Początek późniejszym innowacjom ekonomicznym dały charyzmaty chrześcijańskie: charyzmat benedyktyński stworzył podstawy europejskiej kultury pracy i ekonomii, charyzmat franciszkański przyczynił się do powstania pierwszej szkoły ekonomii opartej na wzajemności i bezinteresowności. Zakładane przez franciszkanów tzw. banki pobożne (Monti di pietà) były pomocą dla niezamożnych rodzin umożliwiając im niskooprocentowane pożyczki i tym samym walcząc z biedą i nieuczciwą lichwą.

Istotne znaczenie dla rozwoju ekonomii społecznej miał XV-wieczny humanizm obywatelski, który doceniając społeczny charakter człowieka zachęcał do tworzenia wspólnot obywatelskich (civitas), aby broniły praw jednostki. Do rozwoju społeczeństwa obywatelskiego przyczyniła się polityka miast włoskich późnego średniowiecza i wczesnego renesansu ${ }^{3}$. Szczególnym momentem dla społecznego wymiaru ekonomii było założenie przez Antonio Genovesi na uniwersytecie w Neapolu w 1755 r. pierwszej katedry eko-

\footnotetext{
Dla ukazania pełni źródeł myśli społecznej należałoby sięgnąć do kart Pisma św. Starego Testamentu, z którego wywodzi się tradycja i kultura chrześcijańska, a w którym znajdują się liczne przykłady nakazów troski o ubogich i sprawiedliwy podział dóbr (por. Wj 23,10; Kpł 25, 35-36; Pp 15, 1-4).

3 Polityka ta opierała się na zasadach równości obywateli, ich partycypacji w sprawowaniu władzy i podejmowaniu decyzji, tworzeniu prawa, a także w społecznym sprawowaniu funkcji publicznych.
} 
nomii ${ }^{4}$. Według niego „ekonomia to miejsce cywilizacji i środek poprawy 'dobrego życia' osób i narodów”, a życie społeczne to "sposobność osiągnięcia szczęścia dzięki dobrym i sprawiedliwym prawom, handlowi i ciałom społecznym, w których ludzie praktykują poczucie społeczne" [Genovesi, 1963/2004].

Wsparcie dla idei ekonomii społecznej można znaleźć także na kartach Teorii uczuć moralnych, jednej z pierwszych książek A. Smitha: „Jakkolwiek samolubnym miałby być człowiek, są niewątpliwie w jego naturze jakieś pierwiastki, które powodują, iż interesuje się losem innych ludzi, i sprawiają, że ich szczęście jest dla niego nieodzowne (...). To, że smutek innych staje się naszym smutkiem, jest sprawą nadto oczywistą, by trzeba na dowód tego szukać przykładów" [Smith, 1989, s. 5]. I dalej: „Nie do pomyślenia jest, abyśmy nie pragnęli szczęścia wszystkich niewinnych, rozumnych istot i nie czuli w jakiejś mierze sprzeciwu wobec ich niedoli, gdy wyraźnie to sobie uświadomimy w naszej wyobraźni. (...) Człowiek mądry i szlachetny zawsze pragnie poświęcić osobistą korzyść na rzecz korzyści ogółu danej grupy czy społeczności. Zawsze też pragnie, by korzyść tej grupy czy społeczności była poświęcona na rzecz większej korzyści dla państwa czy monarchii, wobec której jest tylko podporządkowaną częścią" [Smith, 1989, s. 350-351].

Smith twierdzi, że także na rynku występują pewne cnoty społeczne, jak roztropność czy sprawiedliwość i można doświadczyć bezinteresownych relacji ludzkich, a nawet przyjaźni. Jednak już kilkanaście lat później poglądy Smitha ulegają dość istotnej zmianie. W Bogactwie narodów pisze: „Nie od przychylności rzeźnika, piwowara czy piekarza oczekujemy naszego obiadu, lecz od ich dbałości o własny interes" [Smith, 1954, s. 5]. Tym stwierdzeniem Smith (a później kontynuato-

4 Była to katedra ekonomii społecznej, chociaż nazywała się Katedrą Handlu i Mechaniki. rzy jego myśli) przesadnie doceniają rynek i indywidualny zysk.

Rozpowszechniający się w Europie utylitaryzm i powstanie społeczności industrialnych w wyniku rewolucji przemysłowej (II poł. XIX w.) wykształciły nowy paradygmat człowieka sukcesu: homo oeconomicus, co wyznaczyło przedmiotowy stosunek człowieka do człowieka i doprowadziło do istotnego zmniejszenia roli ekonomii społecznej ${ }^{5}$. Sprzeciwiała się temu chrześcijańska myśl społeczna, co znajdowało wyraz w licznych inicjatywach społecznych duchowieństwa i wspólnot chrześcijańskich oraz w nauczaniu społecznym Kościoła katolickiego (Rerum novarum Leona XIII z 1891 r.).

W ostatnich dekadach XX w. nastąpił powrót idei społecznych i pojawiło się nowe spojrzenie na problem niesprawiedliwości oraz dążenie do równomiernego rozwoju i wyeliminowania ubóstwa. Zarówno w Nauce Społecznej Kościoła ${ }^{6}$, jak i w działalności różnych zgromadzeń zakonnych, wspólnot, ruchów i stowarzyszeń wyraża się dążenie do poprawy warunków życia osób najuboższych oraz do przeciwdziałania zjawisku wykluczenia społecznego. Tradycja chrześcijańska ma w tej dziedzinie ogromne osiągnięcia - zarówno dzięki aktywności pojedynczych osób, jak i przez działalność zinstytucjonalizowaną (zakony, zespoły charytatywne, Caritas).

W społecznościach innych religii także widoczne są dążenia do zmian uwarunko-

\footnotetext{
Modernistyczna ekonomia zastąpiła zasadę wzajemności, będącą filarem przedmodernistycznych porządków społecznych, zasadą wymiany ekwiwalentnej (instrumentalnymi mechanizmami rynkowymi). W rezultacie przedmodernistyczna „wspólnota” zorientowana na osobę została zastąpiona anonimowym, nieosobowym "społeczeństwem" rynkowym. Nowoczesna ekonomia polityczna jest właściwie potomkiem tradycji obywatelskiego humanizmu XV-wiecznego, zatem i greckiego i chrześcijańskiego. Tak więc zarówno Smith, jak i Genovesi nie są ostatnimi myślicielami przedmodernistycznymi (jak się ich zwykle przedstawia), ale są reprezentantami starej tradycji, która także po nich trwała nadal w modernistycznej ekonomii [Bruni, Zamagni, 2004].

6 Encykliki Laborem exercens (1981) oraz Centesimus annus (1991) Jana Pawła II.
} 
wań ekonomicznych i poprawy życia ludzi: w judaizmie - ruch kibuców stosujący zasady religii żydowskiej do rozwiązywania problemów społecznych i gospodarczych, w islamie -działalność Grameen Banku M. Yunusa (Bangladesz) walczącego z ubóstwem nawet kosztem narażenia się ortodoksyjnym muzułmanom, w buddyzmie - inicjatywy gospodarcze nie nastawione na zysk, zwykle związane z działalnością buddyjskich mnichów utrzymujących się i pomagających ubogim wyłącznie z darowizn.

Także inicjatywy świeckie są źródłem wspólnotowych doświadczeń ekonomicznych, np. New Harmony Owena, banki spółdzielcze Raiffeisena, czy kasy Stefczyka (łącznie $z$ obecnie rozwiniętym $w$ wielu krajach ruchem spółdzielczym).

Teoria ekonomiczna w końcowej dekadzie XX w. uważała działania w zakresie ekonomii społecznej za marginalne, stanowiące wyjątki od ogólnej zasady ekonomii określonej jako for profit. Natomiast P. Drucker w 1999 r. twierdził, że w XXI w. sfera biznesu rozumianego jako zorganizowana forma działalności gospodarczej będzie się kurczyła, ustępując miejsca innym sektorom, z których największe znaczenie będzie miał przypuszczalnie sektor niedochodowych organizacji społecznych [Drucker, 1999/2009, s. 11].

W ramach ekonomii społecznej realizowane są działania ukierunkowane na przeciwdziałanie wykluczeniu licznych grup społecznych, często pomijanych na rynku pracy, jak niepełnosprawni, bezdomni, bezrobotni, byli więźniowie.

Jako główne mechanizmy funkcjonowania ekonomii społecznej należy wymienić: stowarzyszenia, towarzystwa (wzajemnej pomocy, ubezpieczeń), spółdzielnie (mieszkaniowe, rolnicze, pracy) oraz przedsiębiorstwa społeczne. Osiąganie celów społecznych uzyskuje się także realizując nowe rozwiązania organizacyjne, takie jak np. spółdzielnie socjalne oraz ośrodki integracji społecznej (dla osób zagrożonych wykluczeniem społecz- nym), centra aktywizacji zawodowej i terapii zajęciowej (dla osób z niepełnosprawnością), czy towarzystwa ubezpieczeń wzajemnych. Różnią się one w zakresie roli, rodzajów produktów i usług, sposobu finansowania oraz podziału zysku.

Podział działalności ekonomicznej według klucza for profit / non profit nie jest właściwy, ponieważ organizacje non profit działają także dla zysku, ale nadają mu inny sens niż w ekonomii klasycznej. Interesująca wydaje się propozycja zamiany negatywnego w swojej wymowie określenia organizacji non profit na bardziej adekwatne „organizacje zorientowane na korzyści społeczne" (social profit oriented) [Wygnański, 2008].

Elementem identyfikującym cechy ekonomii społecznej jest przedsiębiorstwo społeczne. Jest ono przedsiębiorstwem, ponieważ produkuje w sposób stabilny dobra i usługi użyteczne przy pomocy ludzi i zasobów materialnych, a właściciele (akcjonariusze) ponoszą znaczne ryzyko ekonomiczne oraz cieszą się istotną autonomią decyzyjną w zarządzaniu. Można też mówić o jego wymiarze społecznym, ponieważ realizuje nadrzędność świadczenia usług dla członków i wspólnoty nad zyskiem, korzysta z zasobów społecznych (darowizny, dotacje, wolontariat), wyzwala inicjatywę wspólnotową, nie uzależnia możliwości podejmowania decyzji (sprawowania władzy) od wielkości wniesionego kapitału. W pewnym sensie przedsiębiorstwo społeczne łączy zatem cechy firmy komercyjnej oraz organizacji pozarządowej.

Pomimo wzniosłych i ogólnoludzkich celów ekonomia społeczna nie ma łatwego pola do działania pomiędzy rynkiem a państwem, a dokładniej pomiędzy zwolennikami egoistycznie realizowanego biznesu a oczekującymi na "należne" im od państwa świadczenia socjalne.

Ekonomię społeczną charakteryzuje aktywne, a nie roszczeniowe usiłowanie rozwiązania problemów społecznych. Podmioty społeczne poszukują efektywnych finansowo 
dróg zaspokajania różnorodnych potrzeb, nie czekając na filantropijną jałmużnę. Zamiast filantropijnej pomocy materialnej ekonomia społeczna ukazuje sposób wyjścia z trudnej sytuacji, zachęca do podjęcia własnej aktywności, zamiast biernego oczekiwania na zmianę losu. Działania w ramach ekonomii społecznej w znacznym stopniu opierają się na solidarności i współpracy, z reguły stawiając sobie za cel dobro wspólne, a nie partykularny, indywidualny czy wąsko grupowy interes.

Warto także przypomnieć, że zasadnicze znaczenie dla rozwoju ekonomii społecznej mają takie elementy kapitału społecznego jak zaufanie i współdziałanie. Ponadto istotną rolę odgrywa w ekonomii społecznej mądre, roztropne i skuteczne udzielanie pomocy i wychowywanie beneficjentów tej pomocy do współdziałania, do podejmowania pracy i odpowiedzialności za siebie i drugich.

\section{Ekonomia komunii - geneza, rozwój i charakterystyka}

Od r. 1943 datuje się początek istnienia Ruchu Focolari, jednego z licznych ruchów eklezjalnych, ale jedynego o silnym zaangażowaniu tak religijnym, jak i społecznym, politycznym, ekonomicznym i kulturowym, promującym integralną wizję człowieka. Obejmuje on swoim zasięgiem blisko 200 krajów i kilka milionów członków i sympatyków. Wśród członków Ruchu praktykowana jest wspólnota dóbr materialnych i niematerialnych oraz dzielenie się nimi w ramach tzw. kultury dawania, przeciwstawnej kulturze posiadania.

\section{Geneza i rozwój ekonomii komunii}

Podczas jednej z podróży, odwiedzając wspólnoty Ruchu Focolari w Brazylii w 1991 r., Chiara Lubich, założycielka i ówczesny prezydent Ruchu, zetknęła się z ogromnym zróżnicowaniem w poziomie życia bogatych mieszkańców Sao Paolo i tych żyjących w skrajnej nędzy w otaczających miasto slumsach (fave- las). To doświadczenie, a także lektura wydanej w tym samym czasie encykliki Jana Pawła II Centesimus annus ${ }^{7}$, zainspirowały ją do zaproponowania przedsiębiorcom należącym do Ruchu podjęcia inicjatyw mających na celu wykorzenienie (a przynajmniej znaczne ograniczenie) skrajnego ubóstwa i wykluczenia społecznego wśród najbiedniejszych członków Ruchu [Torno, 2013, s. 107]. Apel o tworzenie lub przekształcanie przedsiębiorstw produkcyjnych i firm usługowych dotyczył zasady podziału zysku, tak aby właściciele nie zostawiali go tylko na rozwój przedsiębiorstw i dla siebie, ale w wolności swojej decyzji przekazywali część zysków na zaspokojenie podstawowych środków do godnego życia osób żyjących w niedostatku oraz na kształtowanie ludzi, chcących realizować i rozwijać ten projekt, zwany ekonomią komunii ${ }^{8}$. Lubich zaproponowała, aby przedsiębiorcy dokonywali podziału zysku na 3 równe części (rozwój firmy, dla ubogich, na formację do kultury dawania), ponieważ jednak ich decyzja jest zawsze podejmowana w wolności, zatem przedsiębiorca sam okre-

\footnotetext{
„Konkretnym wyrazem miłości do człowieka, a przede wszystkim do ubogiego, w którym Kościół widzi Chrystusa, jest $<<$ umacnianie sprawiedliwości>>. Pełna sprawiedliwość stanie się możliwa dopiero wówczas, gdy ludzie nie będą traktować ubogiego, który prosi o wsparcie dla podtrzymania życia, jak kłopotliwego natręta czy jako ciężar, ale dostrzegą w nim sposobność do czynienia dobra dla samego dobra, możliwość osiągnięcia bogactwa większego. Jedynie z taką świadomością można odważnie podjąć ryzyko i dokonać przemiany, która wiąże się z każdą autentyczną próbą przyjścia z pomocą drugiemu człowiekowi. Nie chodzi bowiem jedynie o danie tego, co zbywa, ale o pomoc do włączenia się w proces rozwoju gospodarczego i cywilizacyjnego całym narodom, które są z niego wykluczone czy pozostawione na uboczu. Stanie się to możliwe nie tylko dzięki wykorzystaniu dóbr, które istnieją w nadmiarze, a które nasz świat wytwarza w obfitości, ale gdy zmienione zostaną style życia, modele produkcji i konsumpcji, utrwalone struktury władzy, na których opierają się dziś społeczeństwa. Nie ma to oznaczać zniszczenia elementów organizacji społecznej, które dobrze zdały egzamin, ale ukierunkowanie ich zgodnie z właściwym rozumieniem dobra wspólnego całej rodziny ludzkiej." [Jan Paweł II, Centesimus annus, n. 58]

8 Pełna nazwa projektu to Ekonomia komunii w wolności (wł.: Economia di comunione in libertà; ang.: Economy of communion in freedom).
} 
śla, czy i jaką część zysku przeznaczyć na poszczególne cele [Lubich, 2001, s. 34].

Taki podział zysków stanowi narzędzie, przez które wspomniane przedsiębiorstwa realizują [Grochmal, 2013, s. 98]:

- pomoc osobom żyjącym w niedostatku (bezpośrednie wsparcie finansowe na podstawowe potrzeby, a także tworzenie dla nich miejsc pracy lub pomoc w rozpoczęciu własnej działalności),

- promowanie tzw. kultury dawania i formacja osób zaangażowanych w ten projekt (wspieranie programów edukacyjnych, rozwój doktryny ekonomii komunii),

- stały i zrównoważony rozwój przedsiębiorstw poprzez efektywne inwestowanie. Projekt ten spotkał się z bardzo pozytywną odpowiedzią wspólnot Ruchu, początkowo w Brazylii, a bardzo szybko także w innych krajach. W ciągu pierwszych 2 lat powstało ponad 300 firm działających w duchu ekonomii komunii. Aktualnie, po blisko 25 latach, tych przedsiębiorstw jest ok. $860^{9}$ na wszystkich kontynentach, a przekazywane zyski jako pomoc dla żyjących w niedostatku oraz na promowanie ekonomii komunii wynosiły od $5.500 € \mathrm{w} 1994$ r. do 1,33 mln € w 2012 r. [da Cruz, Bidone, 2012, s. 6).

Idea ekonomii komunii powstała w celu rozwiązania konkretnego problemu biedy i nierówności poziomu życia w wymiarze lokalnym, jednak w bardzo krótkim czasie zasięg oddziaływania stał się globalny. Firmy ekonomii komunii, w większości stanowiące własność prywatną (ok. 55\%), przybierają różne formy prawne, przewidziane przez prawodawstwo w danym kraju. Są to zarówno przedsiębiorstwa produkcyjne (ok. 30\%), jak i usługowe (40\%) oraz handlowe (ok. 20\%). W większości są to firmy nieduże, zatrudniające kilka lub kilkanaście osób, są jed-

9 Ta liczba dotyczy nowych firm i jest pomniejszona o liczbę firm, które z różnych powodów przestały istnieć; we współczesnej gospodarce dynamika powstawania i zamykania firm (zwłaszcza małych) jest bardzo duża. nak także takie, które liczą dziesiątki czy setki pracowników ${ }^{10}$.

Projekt ekonomii komunii stanowi istotne wyzwanie wobec dychotomicznego modelu państwo-rynek, bowiem nie liczy na efektywne działanie państwa w likwidacji biedy, lecz wykorzystuje rynek jako środek do redystrybucji zysku i tym samym równomiernego rozłożenia bogactwa. W ekonomii komunii nie oddziela się zatem wytworzenia bogactwa od jego dystrybucji [Zamagni, 2009, s. 77].

\section{Potrzeba zmiany mentalności}

Ekonomia komunii proponuje nowy styl zarządzania przedsiębiorstwem, w którym zasadniczym celem jest nie zysk, ale człowiek widziany integralnie z wszelkimi jego potrzebami i możliwościami, z zachowaniem pełnego poszanowania prawa i etyki biznesu oraz troski o środowisko naturalne. Promuje nowy sposób myślenia i nową hierarchię wartości w zarządzaniu przedsiębiorstwem, ukierunkowaną na solidarność i braterstwo, zgodnie z zasadą, że współczesne przedsiębiorstwo winno stanowić wspólnotę osób wyznających te same wartości, a nie wspólnotę kapitału.

Istotnym skutkiem realizowania ekonomii komunii (oprócz konkretnej pomocy dla osób żyjących w ubóstwie i wykluczonych społecznie) jest zmiana mentalności i kultury życia nie tylko przedsiębiorców [Grochmal, 2014]. Promowanie kultury dawania (dzielenia się dobrami) zamiast kultury posiadania (gromadzenia a także marnotrawienia dóbr), powoduje nowe spojrzenie na pojęcie dobra, a często i sensu życia, zarówno wśród przedsiębiorców, jak i wśród beneficjentów pomocy, ale także wśród klientów, dostawców a nawet konkurentów firm ekonomii komunii [Miłkowski, 2001 i 2008]. Ponadto kultura komunii zmienia nie tylko postawy poszczególnych osób w firmie i jej otoczeniu, ale sprawia, że tworzą się w przedsiębiorstwie „struktury

10 Według wykazu przedsiębiorstw ekonomii komunii; www. edc-info.org/it/business (15.05.2013). 
komunii", umożliwiające realizowanie w nim miłości wzajemnej.

Komunia pomiędzy osobami różni się od relacji solidarności, przyjaźni czy zwykłego koleżeństwa. Komunia jest wynikiem wzajemności oraz zbieżności celów, charakteryzuje ją uniwersalność oraz ukierunkowanie na dobro wspólne. Bycie w komunii z drugim oznacza pełne i wzajemne zaangażowanie się w sprawy drugiego, jego radości i jego smutki, sukcesy i porażki. Spotkanie osób w relacji komunii opiera się na dialogu, zaufaniu i wzajemności, dzięki czemu daje zawsze szansę na wzajemne ubogacenie się. Zatem w ekonomii komunii nie mówi się o hojności, dobroczynności czy filantropii; wzajemne relacje buduje się w wymiarze bezinteresownego daru oraz podarowania siebie jako istotnego warunku istnienia osoby ludzkiej. „Ta autentyczna sztuka daru wyzwala całą gamę wartości, jakie określają akt daru: darmowość, radość, hojność, wspaniałomyślność, bezinteresowność, i tym samym chronią relacje przed ryzykiem bycia źle zrozumianym czy wykorzystanym" [Araujó, 2000, s. 36].

Często pojawia się pytanie o motywację przedsiębiorców, którzy podejmują ryzyko oraz poświęcają swój czas, siły, zasoby, zdolności i pieniądze, aby wytwarzać zyski nieprzeznaczone w całości dla nich samych. Świadectwa licznych przedsiębiorców potwierdzają ich rozumienie prymatu osoby przed wszelkimi dobrami materialnymi, ukazują ich autentyczną radość z udzielanej pomocy dla drugich oraz świadczą o znaczących przemianach i nowej kulturze organizacyjnej w prowadzonych przez nich firmach [Gold, 2000; Barrale, 2004; Bruni, Sena, 2012; Notiziario EdC].

Inspiracją projektu ekonomii komunii jest duchowość jedności praktykowana w Ruchu Focolari oraz Nauka Społeczna Kościoła. Do projektu przystąpiły jednak także osoby wyznające religie niechrześcijańskie, a również takie, które nie kierują się motywami religijnymi, lecz pragnieniem realizowania spra- wiedliwości społecznej na gruncie wartości uniwersalnych.

Klasyczna ekonomia kapitalistyczna, wspierana przez współczesną socjotechnikę mediów, dąży do zaspokojenia rozmaitych potrzeb materialnych człowieka, widzianego przede wszystkim jako producenta i konsumenta. Ekonomia komunii dąży do czegoś więcej - nie negując potrzeb materialnych ukazuje istotny cel ludzkiego istnienia, jakim jest dawanie siebie drugim przez miłość, która powinna znaleźć miejsce także w działalności ekonomicznej, a w konsekwencji uszczęśliwić obydwie strony procesu dawania. Ekonomia komunii odpowiada na tzw. paradoks szczęścia w ekonomii, proponując zastąpienie bogacenia się (często kosztem innych) - dzieleniem się dobrami z drugimi, bowiem nie można być szczęśliwym samemu [Grochmal, 2013, s. 100].

Dzielenie się i wzajemne ubogacanie - zarówno dobrami materialnymi, jak i duchowymi - jest zasadniczą przesłanką nowego stylu zarządzania przedsiębiorstwem. Dobro trzymane zazdrośnie tylko dla siebie zubaża jego posiadacza, bo pozbawia go zdolności daru i wzajemności, które są prawdziwym dziedzictwem człowieka, dającym szczęście [Bruni, 2008, s. 366].

W procesie wspomagania potrzebujących w ekonomii komunii nie ma filantropijnej pompatyczności czy upokarzania zasiłkiem socjalnym, ale współudział, gdzie każdy daje i otrzymuje z jednakową godnością [Bruni, Zamagni, 2004, s. 28]. Relacje z potrzebującymi nie są asymetryczne, jak w typowych inicjatywach charytatywnych i filantropijnych, ale opierają się na wzajemności. Ponadto, inaczej niż to się zwykle dzieje w filantropijnym obdarowaniu ubogiego (niekiedy z potrzeby serca, niekiedy dla zaspokojenia własnego sumienia), beneficjent otrzymujący pomoc materialną, uczestnicząc świadomie w całym projekcie ekonomii komunii, stara się otrzymaną pomoc dobrze wykorzystać, często inwestując w swoją działalność gospodarczą 
lub podejmując oferowaną pracę, mając na uwadze nie tyle zaspokojenie doraźnych potrzeb, ile perspektywiczne poprawienie swojego stanu.

Przedsiębiorstwa ekonomii komunii działają w tej samej rzeczywistości ekonomicznej, co inne firmy for profit, w ramach takich samych zobowiązań prawno-podatkowych i uwarunkowań rynkowych, cenowych czy konkurencyjnych, stosując w celu osiągnięcia zysku kryteria skuteczności i efektywności. Maksymalizacja zysku (będąca dla innych firm głównym celem działalności) jest środkiem do osiągnięcia celu, jakim jest wykorzenienie (lub przynajmniej ograniczenie) biedy i rozpowszechnianie nowej kultury.

Realizacja podziału zysku w firmach ekonomii komunii jest nowym i radykalnym rozwiązywaniem problemu ubóstwa, jest to jednak tylko jeden z wielu aspektów ekonomii komunii. W istocie jest ona czymś więcej; jest przede wszystkim postawieniem osoby ludzkiej w centrum wszystkich relacji - zarówno wewnątrz, jak i na zewnątrz przedsiębiorstwa. Wyraża się nie tylko w uznaniu godności i wartości osób żyjących w niedostatku, ale także w pełnym dowartościowaniu kapitału ludzkiego w przedsiębiorstwie. Z takiej postawy wynika żądanie godnych warunków życia pracowników, ale także wymaganie ich odpowiedzialności względem firmy i szeroko rozumianej wspólnoty pracowniczej. Jest to element kształtowania w przedsiębiorstwach ekonomii komunii nowej kultury organizacyjnej [Grochmal, 2011, s. 63].

Jednym z ważnych celów tych przedsiębiorstw jest promowanie różnych inicjatyw w celu rozpowszechniania idei ekonomii komunii; stąd liczne kontakty przedsiębiorców ze studentami (przyjmowanie na praktyki), naukowcami, mieszkańcami okolicznych miejscowości, beneficjentami pomocy, artystami. Dzięki tym różnorodnym kontaktom firmy ekonomii komunii nie tylko stanowią nowy typ przedsiębiorstwa (nowy styl zarządzania, walka z ubóstwem), ale stają się one miejscem realizacji nowej koncepcji rynku i ekonomii, uprzywilejowanym miejscem, w którym żyje się zasadami wzajemności i bezinteresowności.

Postawy kształtowane i realizowane w firmach ekonomii komunii dotyczą zachowań w konkretnych, codziennych i naturalnych przypadkach, a nie w dążeniu do abstrakcyjnego dobra w sytuacjach wyjątkowych czy nadzwyczajnych. Biela nazywa taką postawę naturalnym personalizmem [Biela, 2011, s. 11].

\section{Ekonomia charyzmatyczna}

Ekonomia komunii jest urzeczywistnieniem charyzmatu jedności stanowiącego podstawę duchowości Ruchu Focolari [Lubich, 2007, s. 91]. Jako ekonomia charyzmatyczna charakteryzuje się m.in. tym, że nie wynika z motywacji ekonomicznej, ale jej źródłem jest pewien ideał, niemający zwykle aspektów ekonomicznych, np. intencją franciszkanów była pomoc ubogim, a nie zakładanie banków. Inną cechą ekonomii charyzmatycznych jest prymat praktyki nad teorią. W przypadku ekonomii komunii wiele doświadczeń zostało wcielonych w życie nie jako implementacja rozważań teoretycznych, ale jako praktyka stosowana przez osoby żyjące tym charyzmatem. Lubich w obliczu skrajnej nędzy i ogromnej niesprawiedliwości w dystrybucji dóbr nie zaproponowała stworzenia centrum naukowego, które mogłoby rozwiązywać konkretne problemy badając założenia i słuszność proponowanej teorii; zwróciła się natomiast do firm, aby przez naturalne "narzędzia” wytwarzania bogactwa, jakimi są przedsiębiorstwa, doprowadzić do zmniejszenia biedy i dysproporcji społecznej.

W przeciwieństwie do wielu modeli ekonomicznych i biznesowych, których przyjęte założenia teoretyczne weryfikuje się później w rzeczywistym świecie, ekonomia komunii, inspirowana przez duchowość Ruchu Focolari i realizowana w praktyce w kilkuset przedsiębiorstwach, dopiero po latach doświadczeń 
stała się przedmiotem rozważań teoretycznych i nowej doktryny ekonomicznej. Idea ekonomii komunii wniosła do debaty naukowej o współczesnej ekonomii takie pojęcia jak dobra relacyjne, bezinteresowny dar, wzajemność, pozwoliła odkryć istotne znaczenie bogactwa i ubóstwa, oraz dobro, jakim są relacje międzyludzkie.

Wieloletnie doświadczenia ekonomiczne wynikające z charyzmatu jedności pozwalają zrozumieć, że powodem ubóstwa materialnego są bardzo często sytuacje, gdy relacje międzyosobowe stają się niewłaściwe, chore lub ich po prostu nie ma. Przyczyną biedy w rodzinie może być zerwany kontakt pomiędzy mężem i żoną, pomiędzy rodzicami i dziećmi, z sąsiadami, w ramach wspólnoty, do której należą. Dotyczy to także wspólnoty, jaką stanowi społeczność państwowa - jeżeli w tej wspólnocie występuje bieda, ubóstwo wśród rodzin, to rodzi się pytanie, jakie są relacje społeczne, ale też i polityczne, pomiędzy władzą a obywatelem, pomiędzy instytucjami a członkami społeczeństwa, czy też złe jest zarządzanie dobrami powierzone rządowi.

\section{Koncepcja i cel ekonomii komunii}

Koncepcja ekonomii komunii jest realizowana na dwóch poziomach: osobowym, gdyż jej zasady oddziałują na postawę moralną przedsiębiorcy i stają się następnie czynnikiem inspirującym kulturę organizacyjną z bardzo silnym wpływem na klimat organizacyjny $w$ firmie, oraz strukturalnym, następującym zwykle po tym pierwszym, gdy dochodzi do przemian organizacyjnych w przedsiębiorstwie na skutek realizacji proponowanych wartości oraz gdy inne podmioty gospodarcze widzą i akceptują w tych firmach elementy nowej kultury organizacyjnej, prowadzącej do społeczeństwa bardziej sprawiedliwego.

Celem ekonomii komunii nie jest stworzenie jakiegoś uniwersalnego modelu ekonomicznego, czy realizowanie systemu produkcyjnego poza ekonomią rynkową. Jest to natomiast pewna nowa koncepcja człowieka widzianego w swojej kompletności społecznej oraz propozycja dla tych, którzy świadomi wartości społecznych zechcą wprowadzić je do ekonomii z perspektywą, w której rozwój przedsiębiorstwa, zadowolenie pracowników oraz eliminacja ubóstwa w społeczeństwie są de facto jednym, wspólnym celem. Ekonomia komunii proponuje przeniesienie relacji takich jak w rodzinie naturalnej, najpierw na rodzinę duchową, związaną wyznawaniem tych samych wartości, żyjącą tą samą duchowością wspólnotową, aby docelowo ogarnąć całą rodzinę ludzką.

Z drugiej strony ekonomia komunii krytykuje logikę ekonomii rynkowej, która nastawiona na maksymalizację zysku pomija takie wymiary jak dar, solidarność, wzajemność, piękno, bezinteresowność, a także duchowość i komunia, które stają się nowymi wyrazami w słowniku współczesnej ekonomii.

\section{W nurcie nauki społecznej Kościoła}

Ekonomia komunii wpisuje się w nurt nauki społecznej Kościoła, dotyczący problematyki ekonomii, pracy, rozwoju i sprawiedliwości społecznej, którą tak wspaniale rozwinął Jan Paweł II, a kontynuował Benedykt XVI. W Caritas in Veritate [Benedykt XVI, 2009, n. 36] stwierdza on, że dla dobrego funkcjonowania porządku społecznego nie wystarcza efektywność i solidarność, niezbędne jest poczucie braterstwa. Właśnie relacje oparte o braterstwo są najważniejszymi relacjami w firmach ekonomii komunii, one generują dobra relacyjne, które z kolei tworzą kapitał relacyjny. Bezinteresowne relacje, takie jak przyjaźń, braterstwo czy miłość Benedykt XVI uważa za istotne wartości ekonomiczne, a następnie stawia propozycję wzbogacenia kapitalizmu wolnorynkowego o elementy ekonomii komunii opartej na braterstwie, darze i miłości [Grochmal, 2012, s. 354; Bazela, 2011 , s. 236]. Widoczne jest, że wizja rozwoju ekonomicznego Benedykta XVI wychodzi poza klasyczne pojęcia etyki społecznej, ta- 
kie jak solidarność, subsydiaryzm czy sprawiedliwość społeczna. Bazela określa propozycję rozwoju ekonomicznego Benedykta XVI mianem kapitalizmu 3.0, czyli trzeciej generacji ${ }^{11}$. Papież proponuje także usunięcie podziałów pomiędzy sferą produkcyjną (wytwarzanie dóbr), sferą polityczną (redystrybucja dóbr) i trzecim sektorem (polityka społeczna, filantropia), widząc w tym szansę na rozwiązanie problemów społecznych i zmniejszenie ubóstwa w świecie przez wprowadzenie logiki daru oraz relacji braterstwa do działalności ekonomicznej. Jest to wyraźne potwierdzenie przez Naukę Społeczną Kościoła założeń ekonomii komunii zaproponowanej przez Lubich w $1991 \mathrm{r}$.

Kluczowym wyróżnikiem tak rozumianej ekonomii jest traktowanie zysku nie jako środka do bogacenia się i powiększania własnego kapitału, ale jako instrumentu do realizacji celów społecznych. Jest to wyzwanie skierowane przede wszystkim do firm i korporacji generujących zysk, na których opiera się gospodarka rynkowa i wolny rynek. Gospodarka ta wyszła zwycięsko ze współzawodnictwa z gospodarką komunistyczną i zapewniła światu olbrzymi postęp. Jednakże postęp ten przyniósł ze sobą także wielkie nierówności pomiędzy ludźmi i nędzę w wielu regionach świata. Jeżeli ma nastąpić zmiana istniejącego stanu rzeczy, trzeba inaczej

\footnotetext{
11 W historii gospodarki wolnorynkowej Bazela wyróżnia trzy okresy. Pierwszy to wiek XIX i I połowa wieku XX, gdy dominował tzw. kapitalizm drapieżny, charakteryzujący się tzw. kwestią robotniczą i próbą jej rozwiązania w encyklice Leona XIII Rerum novarum. Drugi okres to II połowa w. XX i pierwsza dekada trzeciego tysiąclecia. Ten okres charakteryzuje encyklika Jana Pawła II Centesimus annus, w której papież pisze, że cywilizacja świata zachodniego przetrwa tak długo, jak długo będzie umiała dbać o godność człowieka, sprawiedliwość społeczną i środowisko naturalne. Natomiast materializm bez etyki i moralności, utylitaryzm i relatywizm doprowadzą do samounicestwienia poprzez totalitaryzm zysku, przyjemności i wygody. Trzecią generację - uważa Bazela - rozpoczyna encyklika Benedykta XVI Caritas in veritate, w której papież proponuje wzbogacić zarządzanie biznesem o idee miłości, braterstwa i daru, aby przełamać tyranię zysku [Bazela, 2011, s. 225].
}

podejść do wytwarzanego w przedsiębiorstwach zysku [Gądecki, 2010, s. 24].

Ekonomia komunii jako ekonomiczny wyraz paradygmatu jedności

Ze względu na nadal obowiązujący w ekonomii rynku model homo oeconomicus postawienie osoby ludzkiej w centrum wszelkich relacji w przedsiębiorstwach ekonomii komunii stawia współczesną ekonomię oraz nauki o zarządzaniu wobec potrzeby wprowadzenia nowego paradygmatu mającego także wymiar kulturowy, społeczny i duchowy (również transcendentny), porównywalnego z „rewolucją kopernikańską" [Calvo, 2009, s. 56]. Takim paradygmatem jest paradygmat jedności, zdefiniowany i opisany po raz pierwszy w naukach społecznych przez A. Bielę [1996] ${ }^{12}$. Paradygmat ten nie jest wynalazkiem czegoś nowego, ale podobnie jak paradygmat kopernikański w naukach przyrodniczych, stawia rzeczy na swoim miejscu, porządkuje relacje pomiędzy wymiarem materialnym (także ekonomicznym) a transcendentnym współczesnego człowieka i społeczeństwa.

Założenia tego paradygmatu oraz jego zastosowanie w psychologii i ekonomii (z perspektywą uogólnienia na wszystkie nauki społeczne) zaprezentował jego twórca - Adam Biela [1996, 2006, 2009], natomiast obszerną analizę paradygmatu jedności w różnych naukach społecznych, oraz jego aplikację w naukach o zarzą dzaniu (łącznie z wynikami badań empirycznych jego stosowania w przedsiębiorstwach ekonomii komunii) przedstawił Grochmal [2013]. W tej pracy udowodniono zgodność paradygmatu jedności z koncepcją paradygmatu według Kuhna [1968], oraz wykazano jego uniwersalność w zarządzaniu przedsiębiorstwami ekonomii komunii niezależnie od ich wielkości, lokalizacji, struktury

\footnotetext{
12 Biela wygłaszając w 1996 roku laudację z okazji nadania Chiarze Lubich doktoratu honoris causa Katolickiego Uniwersytetu Lubelskiego, określił ekonomię komunii jako fenomen, który w naukach społecznych może być porównywany z rewolucją kopernikańską w naukach przyrodniczych [Biela, 1996, s.196].
} 
własności i branży, a także niezależnie od uwarunkowań prawno-organizacyjnych i społecznych w różnych krajach, ukazując także jego szczególne znaczenie $w$ rozwiązywaniu problemów wobec kryzysu nie tylko ekonomicznego, ale kulturowego i społecznego.

Na podstawie przytoczonych cech ekonomii komunii można stwierdzić, że nie jest ona marginalnym doświadczeniem realizowanym przez poczciwych przedsiębiorców, którzy usiłują wypełnić lukę w dominującej ekonomii kapitalistycznej, ale jest w pełnym znaczeniu tego słowa nową wizją ekonomii. Jest ona nowym spojrzeniem, którego nie można kwalifikować według typowego dla ekonomii kapitalistycznej podziału na firmy for profit i non profit. Niektórzy ekonomiści przyrównują ekonomię komunii do paradygmatu przedsiębiorstw for project, typowego dla ekonomii społecznej, w którym przedsiębiorcy uczestniczą we wspólnych projektach [Bruni, 2010].

\section{Ekonomia społeczna a ekonomia komunii: analogie i różnice}

Powyższa prezentacja ekonomii komunii upoważnia do postawienia tezy o jej silnym związku z ekonomią społeczną, o istniejących podobnych elementach teleologicznych, pomimo stosowania różnych metod oraz często różniących obie ekonomie inspiracji.

W literaturze nie ma zbyt wielu pozycji z zakresu analizy porównawczej ekonomii komunii i ekonomii społecznej. Interesujące źródło stanowi cykl artykułów w czasopiśmie Impresa Sociale [2009], w większości jednak odnoszących się do uwarunkowań włoskich. W jednym z artykułów Crivelli i Gui dokonują analizy podobieństwa ekonomii komunii z dwoma północnoamerykańskimi kierunkami ekonomii społecznej: modelem Social Entrepreneurship School i szkołą przedsiębiorczości społecznej Social Innovation oraz z europejskimi doświadczeniami współdziałania społecznego w ramach Europejskiej Sieci Badawczej EMES. Wykazują oni istot- ne analogie, ale również zróżnicowanie ekonomii komunii i wymienionych kierunków, zwracając uwagę na wieloaspektowy wymiar ekonomii społecznej [Crivelli, Gui, 2009, s. 20]. Uniwersalny charakter ekonomii komunii w rozwiązywaniu problemów społecznych (głównie w Ameryce Łacińskiej) ukazuje Calvo [2009], natomiast zarządzanie w warunkach kryzysu w firmach o motywacji ideowej (jakimi są przedsiębiorstwa społeczne i ekonomii komunii) omawiają Bruni i Smerilli [2009].

W ekonomii społecznej jest jasno sformułowana misja społeczna, przez którą realizowane jest oddziaływanie na społeczeństwo, generując pewne wartości społeczne [Peredo, McLean, 2014, s. 81), nawet niekiedy kosztem efektów ekonomicznych ${ }^{13}$. Niemniej jednak uzyskiwanie dochodów, tworzenie miejsc pracy oraz działalność o charakterze komercyjnym jest także obiektem przedsięwzięć w ekonomii społecznej. W firmach ekonomii komunii mamy do czynienia z działalnością komercyjną, a więc generującą zysk, natomiast jego dystrybucja ma charakter społeczny. Pomimo zbieżnych celów z ekonomią społeczną, ekonomia komunii odróżnia się inaczej przyjmowaną aksjologią: stawia jako najważniejszą wartość osoby ludzkiej z wszystkimi tego konsekwencjami.

Działania ekonomii społecznej są zwykle podejmowane pod wpływem impulsu jednej czy wielu osób w celu rozwiązania jakiegoś problemu społecznego. Często popełnia się istotny błąd $\mathrm{w}$ realizacji tych celów społecznych, "kochając, ale bez bycia miłością" [Ferrucci, 2009, s. 199], bowiem nie dostrzega się szerokiej perspektywy osób, którym pragnie się pomóc, nie traktując ich jak braci z równą godnością. Ekonomia komunii stawia

\footnotetext{
13 Mogą występować przypadki, gdy organizacja non profit generuje zysk, ale jej głównym celem jest wytwarzanie korzyści społecznych, tzw. organizacje hybrydowe (np. Grameen Bank w Bangladeszu); przedsiębiorczość społeczna obejmuje także przypadki, gdy przedsiębiorstwo samo w sobie nie generuje wartości społecznych, ale wspiera inne działania społeczne.
} 
na pierwszym miejscu komunię, tak w procesie wytwarzania dóbr, jak i przy ich dystrybucji, czyli budowanie relacji braterskich, w których nie wyróżnia się ofiarodawcy i beneficjenta, ponieważ wszyscy stanowią część braterskiej wspólnoty dóbr.

W ekonomii społecznej działania ekonomiczne są traktowane jako służba wobec drugiego człowieka, natomiast w ekonomii komunii są one rozumiane jako relacja miłości, pozwalająca na wspólną realizację siebie i drugiego.

Ekonomię komunii charakteryzuje ponadto szczególny wymiar społeczny. Motywująca działania ekonomiczne zasada wzajemności, niemająca nic wspólnego z ekwiwalentną wymianą towarów, powoduje powstawanie wartości stanowiących silne więzy społeczne, wpływa na formację osób w kierunku szukania dobrobytu dla siebie i dla innych przez działania społeczne stanowiące wartość samą w sobie, a nie tylko jako narzędzie do osiągnięcia korzyści indywidualnych.

Różnice pomiędzy obydwoma realizacjami działalności ekonomicznej występują m.in. w przyjętych metodach. Ekonomia społeczna dąży do sprawiedliwego podziału dóbr uzyskanych w wyniku działalności gospodarczej nie nastawionej na zysk, ekonomia komunii proponuje działania komercyjne, a osiągnięty zysk przeznacza w części na cele społeczne. Takie zróżnicowanie nie zawsze jest uzasadnione, gdyż z jednej strony także organizacje non profit mogą wypracowany zysk przeznaczyć na określone statutowo cele, a z drugiej strony w projekcie ekonomii komunii mogą uczestniczyć np. spółdzielnie, zgodnie z przyjętym zapisem w ich statucie oraz zależnie od obowiązującego w danym państwie prawa handlowego i podatkowego. Realizacja przyjętych celów społecznych jest także uwarunkowana akceptacją takich zamierzeń przez akcjonariuszy przedsiębiorstwa czy organizacji, posiadających udziały w kapitale lub prawo do decyzji o przeznaczeniu wypracowanych zysków.
Bardziej istotną różnicą jest sposób reagowania na mechanizmy rynkowe. Podmioty ekonomii społecznej często podejmują się doraźnych przedsięwzięć; niekiedy wydaje się, jakby ekonomia społeczna nie dowartościowywała praw rynku i niezbędnej efektywności przedsiębiorstw. Często organizacje non profit nie potrafią reagować na skutki mechanizmów rynkowych, bagatelizują ten problem lub nie mają niezbędnych narzędzi do efektywnego zarządzania, umiejętności efektywnego wykorzystywania zasobów, oceny uzyskanych wyników ekonomicznych. Może to prowadzić do upadku firmy lub znacznych strat ekonomicznych, a także postrzegania organizacji społecznych przez biznes jako nieefektywnych lub niegospodarnych.

W tym aspekcie ekonomia społeczna może skorzystać z doświadczeń ekonomii komunii, gdzie mechanizmy rynkowe są traktowane jak w każdym innym przedsiębiorstwie komercyjnym, a także z doświadczeń, jak uniknąć błędów ekonomii kolektywistycznej i socjalistycznej, której pewne cechy może niekiedy przyjmować ekonomia społeczna.

Istotną różnicą ekonomii komunii wobec działań w ramach ekonomii społecznej są relacje (opisane wcześniej) pomiędzy przedsiębiorstwem a biednymi i wykluczonymi społecznie. Nie są to klasyczne relacje darczyńcy wobec beneficjenta pomocy, ale pełne godności, równości i wzajemności relacje pomiędzy uczestnikami tego samego projektu. W relacjach pomiędzy biznesem a przedsiębiorstwami społecznymi (a także innymi organizacjami non profit) zaczyna być widoczne przejście od paternalistycznej filantropii do partnerstwa. Organizacje te przestają być jedynie odbiorcą pomocy, a stają się pośrednikiem umożliwiającym firmom angażowanie się w korzystne dla wszystkich stron długofalowe programy społeczne [Rok, 2004, s. 7].

Pomiędzy obiema wizjami ekonomii widoczne są także różnice o charakterze motywacyjnym: przedsiębiorcy ekonomii komunii podejmują decyzję w wyniku osobistych wy- 
borów życiowych, w ekonomii społecznej są to najczęściej decyzje o charakterze zawodowym lub wolontariatu. Nie bez znaczenia jest również fakt odczuwania silnej więzi wspólnotowej w firmach ekonomii komunii, która wpływa na podejmowane decyzje.

Przedsiębiorca społeczny to osoba podejmująca ryzyko, dostrzegająca możliwości oraz innowacyjny charakter działań ekonomicznych, a także charakteryzująca się oryginalną pomysłowością i wyobraźnią przełożenia działań ekonomicznych na efekt społeczny (nie zawsze tożsamy z sukcesem ekonomicznym) [Peredo, McLean, 2014, s. 80]. Przedsiębiorcę ekonomii komunii można scharakteryzować analogicznie, dodając jednak inną motywację podejmowanych przedsięwzięć: oprócz efektu społecznego w wymiarze materialnym (ograniczenie ubóstwa) ważny jest aspekt niematerialny, duchowy i kulturowy, uwzględniający integralny wymiar człowieka i organizacji.

Ekonomia społeczna stawia sobie za cel stworzenie szansy osobom dotkniętym ubóstwem na wyjście z biedy, wyzwolenie z pozycji klienta, przedmiotu filantropii i pomocy socjalnej, pozycji osoby zależnej od pomocy innych, a więc szansy na samodzielną zdolność zadbania o los swój i swoich najbliższych. Także dla organizacji celem jest wyzwolenie od postawy jałmużnika i uzależnienia od preferencji publicznych i prywatnych sponsorów. W tym zakresie ekonomia komunii, ukazując ważną rolę ducha przedsiębiorczości realizowanej dla celów społecznych, nie tylko może stać się istotnym, doświadczonym doradcą ekonomii społecznej, ale może ją ubogacić integralną wizją człowieka i organizacji, całym pozaekonomicznym bogactwem idei ekonomii komunii, jaki stanowią kapitał relacyjny, duchowy i ludzki [Grochmal, 2016].

Należy podkreślić istotne znaczenie aspektu duchowego (religijnego) w przedsięwzięciach ekonomii komunii. Rozwój tej idei nie byłby możliwy, gdyby jej projekt nie został zasiany na dobrze przygotowany grunt wspólnoty Ruchu Focolari. W tej bowiem wspólnocie praktykowanie od wielu lat ewangelicznej miłości bliźniego w wymiarze indywidualnym i społecznym, życie kulturą dawania i szerzenie charyzmatu jedności stworzyło warunki do wcielenia w życie i szybkiego rozwoju tej idei. Duchowość Ruchu Focolari i jej praktykowanie w życiu codziennym dają wielu przedsiębiorcom ekonomii komunii siłę do podejmowania i realizowania trudnych zadań a beneficjentów utwierdzają w przekonaniu o ojcowskiej miłości Boga.

Doświadczenia ekonomii komunii inspirowane chrześcijańską myślą społeczną, a w szcze gólności Katolicką Nauką Społeczną, mogą stanowić znaczące wsparcie dla rozwoju ekonomii społecznej oraz być pomocą w urzeczywistnieniu w przedsiębiorczości takich haseł, jak wzajemność, bezinteresowność, braterstwo, dar. Rozwinięta doktryna ekonomii komunii może też ukierunkować naukowców na nowe problemy ekonomii i polityki społecznej. Z innej strony, rozwinięte metody naukowe badające procesy ekonomii społecznej mogą stanowić istotne wsparcie $\mathrm{w}$ zastosowaniu metodologii badawczych w ekonomii komunii.

Właściciele firm ekonomii komunii często uzasadniają efekty działań swoich przedsiębiorstw i pomoc w rozwiązywaniu trudnych problemów zarządzania firmą działaniem niewidzialnego Wspólnika, ekonomicznego Partnera, jakim jest Boża Opatrzność. Można przytoczyć setki doświadczeń, które potwierdzają to zaufanie, często wyrażane przez przedsiębiorców słowami: jeżeli moje działania ekonomiczne są właściwe, uczciwe i sprawiedliwe, to często są one potwierdzane przez Bożą interwencję w działaniu firmy, zwłaszcza wtedy, gdy „po ludzku” nie można spodziewać się takich rozwiązań [Miłkowski, 2008, s. 158].

\section{Podsumowanie}

Ekonomia społeczna i ekonomia komunii proponują współczesnemu światu roz- 
wiązanie problemów społecznych w celu ograniczenia ubóstwa i wykluczenia społecznego. Z przytoczonej analizy wynika, że obydwie wizje ekonomii mają wiele cech wspólnych i mogą się wzajemnie uzupełniać i wspierać. Bliskie sobie są źródła ekonomii społecznej i ekonomii komunii: potrzeba dialogu, poczucie solidarności, sprawiedliwości i odpowiedzialności społecznej, wrażliwość na niedostatek i wykluczenie społeczne oraz chęć pomocy tym, którzy w wyniku niesprawiedliwego podziału dóbr nie są w stanie żyć w godnych warunkach [Defourny, Develtere, 2008; Filek, 2012; Lubich, 2007]. Te wspólne antropologiczne i etyczne wartości w ekonomii komunii konkretyzują się w nieco odmienny sposób, niż w ekonomii społecznej.

U podstaw przedsięwzięcia ekonomii komunii leży miłość wzajemna i przekonanie o możliwości budowania wspólnoty nie jako kolektywu, ale jako prawdziwej komunii osób.

\section{Literatura}

Araùjo V. (2000). "Quale visione dell'uomo e della società?", w: L. Bruni , V. Moramarco (red.), L'Economia di Comunione: verso un agire economico a "misura di persona". Mediolan: Vita e Pensiero.

Barrale S.G. (2004). L'Economia di Comunione (EdC): aspetti e problemi per una nuova cultura aziendale, Tesi di laurea in Economia e Commercio. Palermo: Università degli Studi di Palermo.

Bazela M. (2011). „Kapitalizm 3.0 według Benedykta XVI. O wizji rozwoju ekonomicznego w Caritas in veritate", Fronda, nr 61.

Benedykt XVI (2009). Caritas in Veritate. Kraków: Wydawnictwo M.

Biela A. (1996). „Przesłanie jedności. Laudacja wygłoszona 19 czerwca 1996 z okazji nadania tytułu doktora honoris causa KUL Chiarze Lubich", Zeszyty Naukowe KUL, nr 39.

Biela A. (2006). „A paradigm of the unity in social sciences", Journal for Perspectives of Economic, Political and Social Integration. Journal for Mental Changes, vol. XII, nr 1-2.

Biela A. (2009). „A paradigm of the unity in psychology", Journal for Perspectives of Economic, Political and Social Integration; Journal for Mental Changes, vol. XV, nr 1-2, Special Edition: Psychology and Communion.

Biela A. (2011). „Paradygmat jedności jako motyw nadania doktoratu honoris causa Chiarze Lubich
Podstawową charakterystyką ekonomii komunii jest realizowanie zasady ewangelicznej jedności i miłości wzajemnej. Wynika ona z przekonania, że bez wzajemności odniesień, żadne dobro nie staje się „dobro-bytem", natomiast nawet wtedy, gdy dobra materialne są znikome i zagrożone, dzięki miłości wzajemnej, nikt w potrzebie nie pozostaje sam [Bruni 2008, s. 366].

W ostatnich dziesięcioleciach coraz częściej w literaturze ekonomicznej pojawiają się terminy, wyrażenia czy koncepcje, które dotychczas były w zasadzie przedmiotem rozważań wyłącznie takich nauk jak psychologia, socjologia czy etyka: altruizm, bezinteresowny dar, wzajemność, zobowiązanie, szczęście, komunia, a nawet miłość. Te pojęcia, odpowiadające istotnym aspektom ludzkiej działalności, nie mogą pozostawać poza tak ważną nauką, jak ekonomia, a szczególnie w odniesieniu do zapewnienia szczęścia człowiekowi i społeczeństwom.

przez Katolicki Uniwersytet Lubelski w czerwcu 1996 roku", w: W. Otrębski (red.), Elementy myśli społecznej Chiary Lubich - 15 rocznica nadania DHC przez Katolicki Uniwersytet Lubelski. Lublin.

Bruni L. (2008). .L'economia di comunione di Chiara. Quando un carisma cambia anche l'economia", Nuova Umanità, vol. XXX, nr 177.

Bruni L., Sena B. (red.) (2012). The Charismatic Principle in Social Life. Oxford: Routledge.

Bruni L., Smerilli A. (2009). "Sull'arte di gestire le crisi nelle organizzazioni a movente ideale", Impresa Sociale, nr 7-9, Trento: Istituto Studi Sviluppo Aziende Nonprofit (ISSAN) Edizioni.

Bruni L., Zamagni S. (2004). Economia civile. Efficienza, equità, felicità pubblica. Bologna: Mulino.

Bruni L., Zamagni S. (2004a). "Concluding remarks", w: P.L. Porta (red.), Economia civile. A debate on L. Bruni and S. Zamagni: Economia civile. Efficienza, equità, felicità pubblica, http://dipeco.economia.unimib.it/ pdf/pubblicazioni/wp76_04.pdf.

Calvo C. (2009). .,L'economia di comunione e l'America Latina. Vie alternative di sviluppo", Impresa Sociale, nr 7-9, Trento: Istituto Studi Sviluppo Aziende Nonprofit (ISSAN) Edizioni.

Crivelli L., Gui B. (2009). „Le imprese di Economia di Comunione sono anch'esse imprese sociali?", Impresa Sociale, nr 7-9, Trento: Istituto Studi Sviluppo Aziende Nonprofit (ISSAN) Edizioni. 
da Cruz I.A.A., Bidone G.M. (2012). „La destinazione di utili e contributi", w: Rapporto EdC 2011-2012; Inserto redazionale allegato a Città Nuova, nr 23/24.

Defourny J., Develtere P. (2008).,Ekonomia społeczna: ogólnoświatowy trzeci sektor", w: J.J. Wygnański (red.), Przedsiębiorstwo społeczne. Antologia kluczowych tekstów. Warszawa: Fundacja Inicjatyw Społeczno-Ekonomicznych.

Drucker P.F. (1999/2009). Management Challenges for the 21st Century, Butterworth-Heinemann, Oxford; tłum. z ang.: P.F. Drucker, Zarządzanie XXI wieku - Wyzwania, MT Biznes, Warszawa.

Ferrucci A. (2009). „Forum”, Impresa Sociale, nr 7-9, Trento: Istituto Studi Sviluppo Aziende Nonprofit (ISSAN) Edizioni.

Filek J. (2009). „Ekonomia społeczna jako nowe wyzwanie", Annales. Etyka w życiu gospodarczym, vol. 12, nr 1, http://www.annalesonline.uni.lodz.pl/archiwum2009.html (dostęp 15.11.2012).

Filek J. (2012). „Teorie filozoficzne a ekonomia społeczna", w: M. Frączek, J. Hausner, S. Mazur (red.), Wokół ekonomii społecznej. Kraków: Małopolska Szkoła Administracji Publicznej Uniwersytet Ekonomiczny w Krakowie.

Gądecki S. abp. (2010). „Filozoficzne podstawy gospodarki społecznej", w: IV Ogólnopolskie Spotkania Ekonomii Społecznej, Poznań.

Genovesi A. (1963/2004). Autobiografia e lettere, Milano: Feltrinelli, [za:] L. Bruni, S. Zamagni (2004a). "Concluding remarks", w: P.L. Porta (red.), Economia civile. A debate on L. Bruni, S. Zamagni: Economia civile. Efficienza, equità, felicità pubblica. Bologna: Mulino.

Gold L. (2000). Making space for sparing in the global market; the Focolare Movement's Economy of Sharing, Thesis for the degree of Ph.D. Glasgow: University of Glasgow.

Grochmal S. (2011). „Kultura organizacyjna przedsiębiorstw ekonomii komunii jako determinanta jej wymiaru społecznego", Acta Universitas Nicolai Copernici, Ekonomia XLII - Nauki Humanistyczno-Społeczne, z. 403, Toruń. DOI: http://dx.doi.org/10.12775/AUNC_ ECON.2011.004.

Grochmal S. (2012). „Ekonomia komunii w praktyce zarządzania przedsiębiorstwem jako systemowo zorganizowana pomoc w celu eliminacji biedy i nierówności społecznych", Prakseologia, nr 153, Instytut Filozofii i Socjologii PAN.

Grochmal S. (2013). Paradygmatjedności w kontekście zarządzania organizacjami. Rzeszów: Wydawnictwo Uniwersytetu Rzeszowskiego.
Grochmal S. (2014). „Mental and cultural changes of enterprise management in accordance with the paradigm of unity", Journal for Perspectives of Economic Political and Social Integration, Journal of Mental Changes, vol. 20, nr 1-2, http://www.degruyter.com/ view/j/pepsi.2014.20.issue-1/v10241-012-0028-0/ v10241-012-0028-0.xml?rskey $=\mathrm{h} 5 \mathrm{qWN} 8$ \&result $=3$. DOI: 10.2478/v10241-012-0028-0.

Grochmal S. (2016).,ISpirituality of unity in management - Economy of Communion", Cogent Business \& Management, vol.3, nr 1; DOl: 10.1080/23311975.2016.1140618; http://dx.doi.org/10.1080/23311975.2016.1140618.

Jan Paweł II (1991). Centesimus annus. Poznań: Pallotinum.

Kuhn T. (1968). Struktura rewolucji naukowych. Warszawa: Wydawnictwo Naukowe PWN.

Lubich C. (2001). L'Economia di Comunione. Storia eprofezia. Roma: Città Nuova.

Lubich C. (2007). Charyzmat jedności. Kraków: Fundacja Mariapoli -Wydawnictwo M.

Miłkowski A. (2001). „Szef mojej firmy”, Nowe Miasto, nr 1-2.

Miłkowski A. (2008). „Ekonomia Komunii”, Nowe Miasto, nr 2-3.

Notiziario Economia di Comunione, http://www. ecodicom.net/notiziario.php.

Peredo A.M., McLean M. (2014). „Przedsiębiorczość społeczna: krytyczny przegląd koncepcji", Ekonomia Społeczna, nr 1 (9).

Pokora M. (2014). „Ekonomia społeczna w polityce przeciwdziałania wykluczeniu społecznemu w Polsce", Ekonomia Społeczna, nr 2 (10).

Rok B. (2004). Odpowiedzialny biznes w nieodpowiedzialnym świecie. Warszawa: Akademia Rozwoju Filantropii w Polsce, Forum Odpowiedzialnego Biznesu.

Smith A. (1954). Badania nad natura i przyczynami bogactwa narodów, t. I. Warszawa: PWN.

Smith A. (1989). Teoria uczuć moralnych. Warszawa: PWN.

Szopa B. (2007). „Ekonomia społeczna z perspektywy ekonomii tradycyjnej", Ekonomia Społeczna, nr 1.

Torno A. (2013). Chiara Lubich. Życie i dzieło. Fundacja Mariapoli - Wydawnictwo Święty Wojciech.

Wygnański J. (2008).,„Ekonomia społeczna - sprzeczność czy konieczność", Więź, nr 4-5.

Zamagni S. (2009). „Fraternità, dono, reciprocità nella Caritas in Veritate", w: Amore e verità, Commento e guida alla lettura dell'Enciclica Caritas in veritate di Benedetto XVI, Milano: Paoline. 
Economy of communion in relation to the social economy - similarities, differences, possibilities of cooperation

Summary: Two ideas of economic activities, the economy of communion and the social economy, seeking to bridge the gap between business (market economy) and the State (distribution of goods), aiming to reduce poverty and social exclusion, have much in common, but in some aspects remain considerably different. This paper allows to understand the idea of the economy of communion in reference to the social economy, its implementation and in reference to social and business tasks which are undertaken by the entrepreneurs of economy of communion. A high similarity of both ideas and opportunities for economic complementarity and cooperation for specific social purposes are demonstrated in the paper.

Keywords: social economy, economy of communion, poverty, social exclusion, Focolare Movement.

\section{Prawa autorskie i licencja / Copyright and License}

(9) $\Theta \Theta \Theta$
Artykuł opublikowano na licencji Creative Commons

Uznanie autorstwa - Użycie niekomercyjne - Bez utworów zależnych 3.0 Polska http://creativecommons.org/licenses/by-nc-nd/3.0/pl/

This article is published under the terms of the Creative Commons Attribution - NonCommercial - NoDerivs (CC BY-NC-ND 3.0) License http://creativecommons.org/licenses/by-nc-nd/3.0/ 